\title{
Rheological model of the lithosphere along profile VII in the Eastern Carpathians
}

\author{
Jana DÉREROVÁ ${ }^{1, *}$ (D) Miroslav BIELIK ${ }^{1,2}$ (D), Igor KOHÚT ${ }^{1}$ (D), \\ Dominika GODOVÁ ${ }^{1,2}$ iD, Andrej MOJZEŠ2 \\ ${ }^{1}$ Division of Geophysics, Earth Science Institute of the Slovak Academy of Sciences, \\ Dúbravská cesta 9, 84005 Bratislava, Slovak Republic \\ ${ }^{2}$ Department of Engineering Geology, Hydrogeology and Applied Geophysics, \\ Faculty of Natural Sciences, Comenius University, \\ Mlynská dolina, Ilkovičova 6, 84248 Bratislava, Slovak Republic
}

\begin{abstract}
We used 2D integrated geophysical modelling approach to calculate the temperature distribution in the lithosphere along profile VII passing through the Eastern Carpathians. With assigned rheological parameters of rocks and obtained temperature field, we derived the rheological model of the lithosphere along the studied profile. We have calculated the strength distribution in the lithosphere, based on the brittle and ductile deformation, for compressional and extensional regimes and the vertically integrated strength along the profile. To illustrate the strength distribution in different tectonic units, we have calculated the yield strength envelopes for chosen lithospheric columns. Ours results show that the dominant regime is compressional and the largest strength occurs on the boundary between the upper and lower crust. Along the studied profile, the strength decreases from its high values in the European platform towards its minimum in the Trans-European Suture Zone (TESZ). In the Eastern Carpathians, the strength increases, reaches two maxima, the first in the Outer Eastern Carpathians, and the second in the Inner Eastern Carpathians, where the highest values of strength can be observed. Another local maximum along the profile can be observed in the Apuseni Mountains, while the minimal strength is observed in the Transylvanian Basin. The diverse rheological behaviour of studied tectonic units seems to be in accordance with their lithospheric structure and tectonics.
\end{abstract}

Key words: rheology, compressional and extensional strength, vertically integrated strength, yield strength envelopes, Carpathian-Pannonian area

\section{Introduction}

The Carpathian-Pannonian-European Platform area, with its geological complexity and variety of different tectonic units, provides a great oppor-

\footnotetext{
*corresponding author: e-mail: geofjade@savba.sk
} 
tunity to study the structure of the lithosphere, the asthenospheric and lithospheric processes taking place within it, and their mutual interaction during the continental collision, the orogeny, volcanic arc and related forearc and back-arc basin development (Ratschbacher et al., 1991a,b; Csontos et al., 1992; Horváth, 1993; Kováč, 2000; Plašienka, 2018).

A variety of geophysical methods has been used to investigate the lithospheric structure of the Carpathian-Pannonian region, such as deep seismic sounding, seismology, gravimetry, magnetometry, magnetotellurics and geothermics (e.g., Lazarescu et al., 1983; Horváth et al., 1986; Horváth, 1993; Mocanu and Radulescu, 1994; Szafián et al., 1997; Fan et al., 1998; Lenkey, 1999; Boykova, 1999; Wortel and Spakman, 2000; Wenzel et al., 2002; Bielik et al., 2005; Dérerová et al., 2006, Raykova and Panza, 2006; Grad et al., 2006; Środa et al., 2006; Mucuta et al., 2006; Hauser et al., 2007; Alasonati Tašárová et al., 2009; Koulakov et al., 2010; Janik et al.,

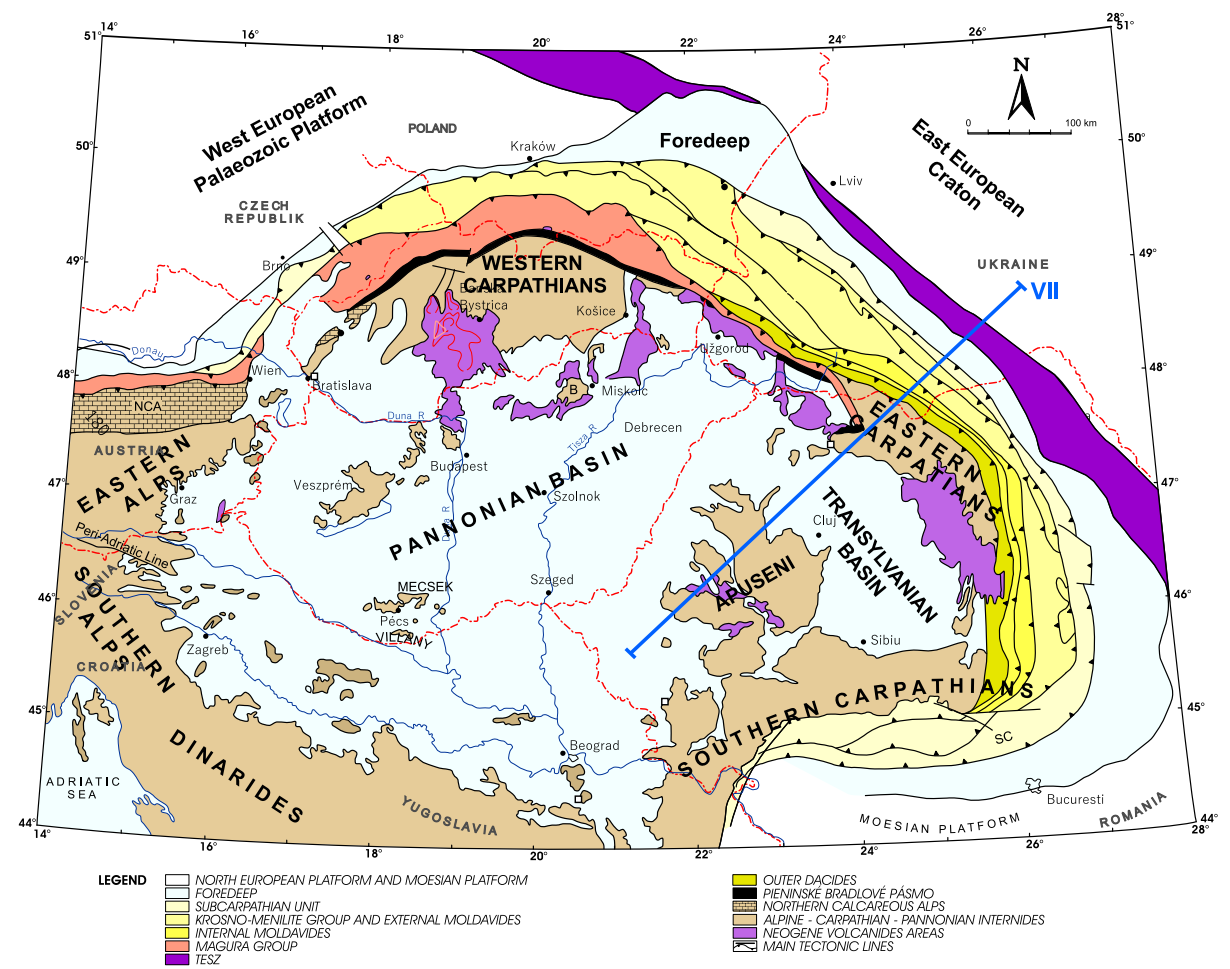

Fig. 1. Location of profile VII on the map of the Carpathian-Pannonian basin region (modified after Bielik, 1998 and Kováč, 2000). 
2011; Grinč et al., 2013; Alasonati Tašárová et al., 2016). These studies provide valuable constrains on tectonic models of the lithosphere of the area.

Incorporating the study of the mechanical structure of the lithosphere and rheology predictions into these tectonic models can provide even more detailed and accurate view and may help to shed some additional light on the mutual interaction among different tectonic units in the CarpathianPannonian-European Platform region. The first rheological models of the lithosphere in the Western Carpathian-Pannonian area have been derived by Bielik and Stríženec (1994), Bielik and Ursiny (1997) and Lankreijer et al. (1999). In the Eastern Carpathians and the Transylvanian Basin, the modelling has been done by Lankreijer et al. (1997), Andreescu and Demetrescu (2001) and more recently by Demetrescu et al. (2007).

In 2012, for the first time, a 2D integrated modelling algorithm was used to calculate the temperature distribution and to derive the rheological model along profile I passing through the Western Carpathian-Pannonian basin region (Dérerová et al., 2012). Later on, we continued in our modelling and calculated rheological models of the lithosphere along profiles II and IV in the Western Carpathians (Dérerová et al., 2014 and 2019). Work presented here is our first attempt to create the rheological model for the lithosphere along a profile running through the Eastern Carpathians.

\section{Profile VII}

Profile VII (Fig. 1) starts in the East European Craton (Ukraine), continues in SW direction through the Outer and Inner Eastern Carpathians, passes through the Transylvanian Basin and Apuseni Mountains to end in the Pannonian Basin. The profile is $520 \mathrm{~km}$ long with following coordinates of starting and ending points, respectively: SP: longitude $26.58^{\circ}$, latitude $48.71^{\circ}$, and EP: $21.54^{\circ}, 45.74^{\circ}$. Lithospheric structure along profile VII (Fig. 2) was previously modelled using $2 \mathrm{D}$ integrated modelling algorithm and published in Dérerová et al. (2006).

\section{Geology}

The European Platform comprises the Precambrian East European Craton (EEC) in the NE and the younger West European Palaeozoic Platform 


\section{Profile Carpathians VII: 26.58/48.71; 21.54/45.74}

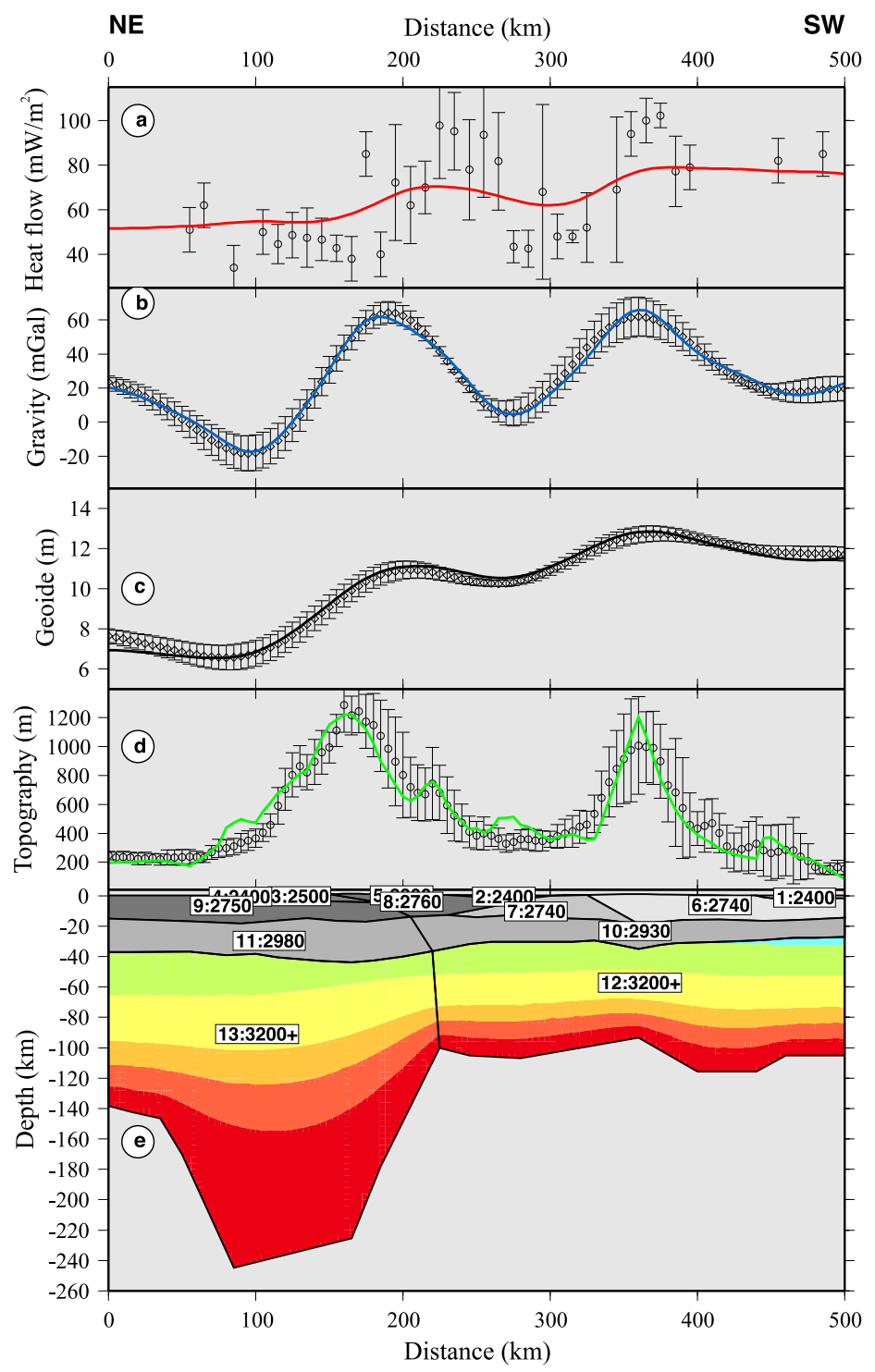

Fig. 2. Lithospheric model along profile VII. (a) Surface heatflow, (b) free air gravity anomaly, (c) topography with dots corresponding to measured data with uncertainty bars and solid lines to calculated values. Numbers in (d) correspond to material number in Table 1b (Dérerová et al., 2006). 
(WEPP) in the NW. After Malinowski et al. (2013), the WEPP crust is heterogeneous, being a tectonic collage of various Palaeozoic terranes accreted to the Baltica margin and affected by the Alpine orogeny in the south. While the Precambrian EEC (a part of the Baltica paleocontinent) is composed of Proterozoic magmatic and metamorphic rocks covered by Vendian and Palaeozoic strata (Środa et al., 2006). Both units are separated by the Trans-European Suture Zone (TESZ).

The Trans-European Suture Zone (TESZ) is the NW-SE trending broad (up to $200 \mathrm{~km}$ ) zone (e.g., Pharaoh, 1999), crossing Europe from the North Sea to the Black Sea. Its southern part is covered by the Carpathian nappes. The TESZ behaves as a weak zone and was several times reactivated by transpressional and transtensional movements (e.g., the Polish Trough Dadlez et al., 1995). This is expressed by numerous subparallel faults called the Teisseyre-Tornquist Zone (TTZ), which represents the most prominent lithospheric boundary in Europe (Pharaoh et al., 2006). The TESZ consists of a collage of Gondwana-related Precambrian and/or Cadomian terranes joined together during pre-Variscan tectonic events and subsequently covered by thick sediments. These terranes were accreted to the south-western margin of the EEC during the Palaeozoic (Lewandowski, 1993; Dadlez, 2001; Belka et al., 2002). The southern edge continues beneath the Carpathian nappes (Dadlez et al., 1994; Malinowski et al., 2005, 2009).

The Eastern Carpathians are formed by the eastward thrust nappe sheets of the Median and Outer Dacides and Moldavides (Săndulescu, 1994) that were stacked during the mid-Cretaceous "Austrian" phase. The Median Dacides (Central East Carpathians) involve basement/cover units attributed to several nappes. The Bucovinian nappe stack is sealed by Albian - Cenomanian post-tectonic cover, but their final thrusting over the more external Outer Dacides was post-Albian in age. The Outer Dacides are already elements of the Carpathian Flysch Belt and are composed of several foldthrust, thin-skinned units. Still more external are the Moldavides - a frontal Carpathian fold-and-thrust system overriding the Neogene foredeep and Phanerozoic cover of the East European Platform. The Moldavides consist of numerous fold-thrust units composed mostly of Cretaceous flysch in the inner subunits. The outer nappes are dominated by Palaeogene sandy flysch deposits. The foredeep includes sediments of Upper Miocene to Quaternary age. The Outer East Carpathian flysch nappes partially overthrust 
the Palaeozoic Trans-European Suture Zone (TESZ).

The Transylvanian Basin is a large, nearly circular depression 150-200 km in diameter that spreads between the Apuseni Mts and the Eastern Carpathians. The basin has a polygenic fill with unconformities between the Upper Cretaceous, Palaeogene and Miocene sediments. The Miocene volcaniclastic, terrigenous and evaporitic sediments are partly related to the Pannonian Basin and can reach thickness greater than $4 \mathrm{~km}$ (Sanders et al., 2002). In general, the basin fill shows only a minor Cenozoic inversion, but numerous Middle Miocene salt diapirs. The basement of the Transylvanian Basin centre is composed of the supra-subduction ophiolite and volcanic island arc complexes of the Transylvanides - their NE continuation from the South Apuseni Mts (Mureş Zone, e.g., Ionescu et al., 2009). However, the position of Transylvanides is not fully understood yet.

The Apusenis are built of numerous, northward-verging thrust sheets emplaced during the mid-Cretaceous period (Inner Dacides in terminology of Săndulescu, 1994). The Bihor "autochthon" in the Northern Apuseni Mts is composed of Pre-Alpine basement and its Permian to Cretaceous sedimentary cover and is overridden by the Codru basement/cover nappe system and the Biharia basement-dominated thrust units. In the Southern Apuseni Mts (Munţii Metaliferi, Mureş Zone), the latter underlie obducted sheets of the Transylvanides - Tethyan ophiolite and island-arc magmatites with related Lower Cretaceous flysch and olistostrome complexes. The post-tectonic formations include the Senonian, Gosau-type shallow-marine terrigenous deposits (e.g., Schuller et al., 2009) and Upper Cretaceous - Palaeogene calc-alkaline magmatites, so-called "banatites". Intramontane grabens are filled with Miocene deposits and acid volcanics.

The Pannonian Basin. The profile passes by its southern part that is filled predominantly by Miocene to Quaternary deposits. The basin basement along the profile is built roughly by the contact between the southern margin of the Tisza block and the obducted Tethyan ophiolites of the Transylvanides (Eastern Vardar Ophiolite Unit, Schmid et al., 2008).

\section{Method}

It is commonly accepted that the mechanical behaviour of the lithosphere can be modelled using experimental constraints on rock rheology (Goetze and 
Evans, 1979, Ranalli, 1995; Kohlstedt et al., 1995). Within the mechanically strong part of the lithosphere, it is possible to define an upper region where the strength of the lithosphere (defined as differential stress necessary to deform a rock) can be described by criteria for brittle failure. For the calculation of the brittle strength of the lithosphere, Byerlee's frictional sliding law can be assumed (Byerlee, 1978):

$\sigma_{\text {brittle }}=\alpha \rho g z(1-\lambda)$,

where $\sigma_{\text {brittle }}$ is the brittle strength [Pa], parameter $\alpha=R-1 / R$ is valid for normal faulting, $\alpha=R-1$ for thrust faulting, $\alpha=R-1 /[1+\beta(R-1)]$ for strike-slip faulting. Parameter $R=\left[\left(1+f_{s}^{2}\right)^{1 / 2}-f_{s}\right]^{-2}$ (known as the stress ratio) depends on coefficient of static friction $f_{s}, \lambda$ represents the hydrostatic pore fluid factor, $\rho$ is material density $\left[\mathrm{kg} \mathrm{m}^{-3}\right], g$ is acceleration of gravity $\left[\mathrm{m} \mathrm{s}^{-2}\right], z$ is depth $[\mathrm{m}], \beta$ is extension factor (Ranalli, 1995).

At the temperatures exceeding approximately half the melting temperature of rock, creep processes become dominant (Carter and Tsenn, 1987). Therefore, the strength in the lower part of the lithosphere is governed by the temperature distribution. Dislocation climb and dislocation glide (Dorn Creep) are the main flow mechanisms occurring in the lower part of the lithosphere (Goetze and Evans, 1979).

Knowing the temperature distribution in the lithosphere, the ductile strength can be calculated assuming power-law dislocation creep equation given as (Ranalli, 1995):

$\sigma_{\text {creep }}=\left(\frac{\dot{\varepsilon}}{A_{p}}\right)^{1 / n} \exp \left[\frac{E_{p}}{n R T}\right]$,

where $\sigma_{\text {creep }}$ is power law creep strength [Pa], $\dot{\varepsilon}$ denotes steady-state strain rate $\left[\mathrm{s}^{-1}\right], A_{p}$ and $n$ (power law exponent) are material creep parameters, $E_{p}$ is power law activation energy $\left[\mathrm{kJ} \mathrm{mol}^{-1}\right], R$ is universal gas constant $\left[8.314 \mathrm{~J} \mathrm{~mol}^{-1} \mathrm{~K}^{-1}\right], T$ is temperature $[\mathrm{K}]$.

Based on the determined temperature distribution and assumed rheological parameters of rocks, the strength distribution can be calculated. For each node, strengths for both brittle and ductile deformation are calculated, with the lesser of these representing the limiting strength of the lithosphere (yield strength) at that particular depth level (Ranalli, 1995; Burov and 
Diament, 1995). The strength distribution, when integrated along vertical lithospheric columns, allows to compare the resistance of the whole lithosphere to stress in different areas.

\section{Results}

The temperature distribution for the lithospheric model along profile VII (Fig. 2) was calculated for every node of the model with 2D integrated modelling algorithm that solves $2 \mathrm{D}$ steady state heat conduction equation. The upper boundary of the model (surface) corresponds to temperature $20^{\circ}$, whilst the lower boundary is limited by $1300^{\circ}$ isotherm that represents the lithosphere-asthenosphere boundary (LAB) in its geothermal definition.

The temperature distribution generally reflects the distribution of the heat sources predominantly in the upper crust, as well as background heat flow density from the mantle lithosphere. The reliability of the temperature model depends on the accuracy and density of measurements of the surface heat flow density data, but the 2D integrated modelling algorithm controls and constrains the lithological model by calculating free air anomaly, geoid and topography that are jointly interpreted.

The resultant picture can be seen in Fig. 3. Temperatures reach values $280-300{ }^{\circ} \mathrm{C}$ at the boundary between the upper and lower crust, $500-700{ }^{\circ} \mathrm{C}$ at the Moho boundary. The deepest Moho located at a depth of about $44 \mathrm{~km}$ under the contact between the Outer and Inner Eastern Carpathians is characterized by temperature of $700^{\circ} \mathrm{C}$. This area is represented by the smallest temperature gradient, while the Pannonian Basin and the Transylvanian Basin by the highest one. Based on the course of $1300^{\circ} \mathrm{C}$ isotherm, we can state that the depth of the LAB along Profile VII changes significantly. The thickest lithosphere $(250-270 \mathrm{~km})$ can be observed beneath the Eastern Carpathians. This lithospheric thickening was interpreted by Dérerová et al. (2006) as remnants of a slab, which started to break off in the Miocene. Towards the Transylvanian Basin the LAB decreases sharply, where it reaches values of only about $100-110 \mathrm{~km}$. The Apusenis are represented by an approximately $130 \mathrm{~km}$ thick lithosphere. The lithospheric thickness of the Pannonian Basin is about $105 \mathrm{~km}$.

The rheological parameters for calculating the brittle and ductile strength of the lithosphere along the Eastern-Carpathian profile VII have been cho- 
sen according to values provided by Goetze and Evans (1979) and Carter and Tsenn (1987) and in agreement with previous rheological modelling in the Western Carpathian-Pannonian region by Lankreijer et al. (1999) and Dérerová et al. (2012, 2014, 2019). Table 1a shows general properties used for the determination of the rheological model based on equations described in section Method, Table 1b specific thermal and rheological parameters entering the model.

Based on the calculated temperature distribution and given rheological parameters, we have calculated the brittle and ductile strength distribution in the lithosphere. The minimum of these two values represents the yield strength, for both compressional and extensional regimes (Figs. 4 and 5). In our calculations we adopted the strain rate value of $10^{-15} \mathrm{~s}^{-1}$. Typical strain rate values for geological settings usually vary from $10^{-13} \mathrm{~s}^{-1}$ (for the areas that deform fast) to $10^{-17} \mathrm{~s}^{-1}$ (for the more rigid areas). This parameter is not very well constrained and may cause a significant difference in the ductile s trength. The average value $10^{-15} \mathrm{~s}^{-1}$ is commonly observed in compressional and extensional settings (Carter and Tsenn, 1987).

The results of yield strength contour plot for both compressional and extensional deformation (Figs. 4 and 5) clearly show that the largest strength

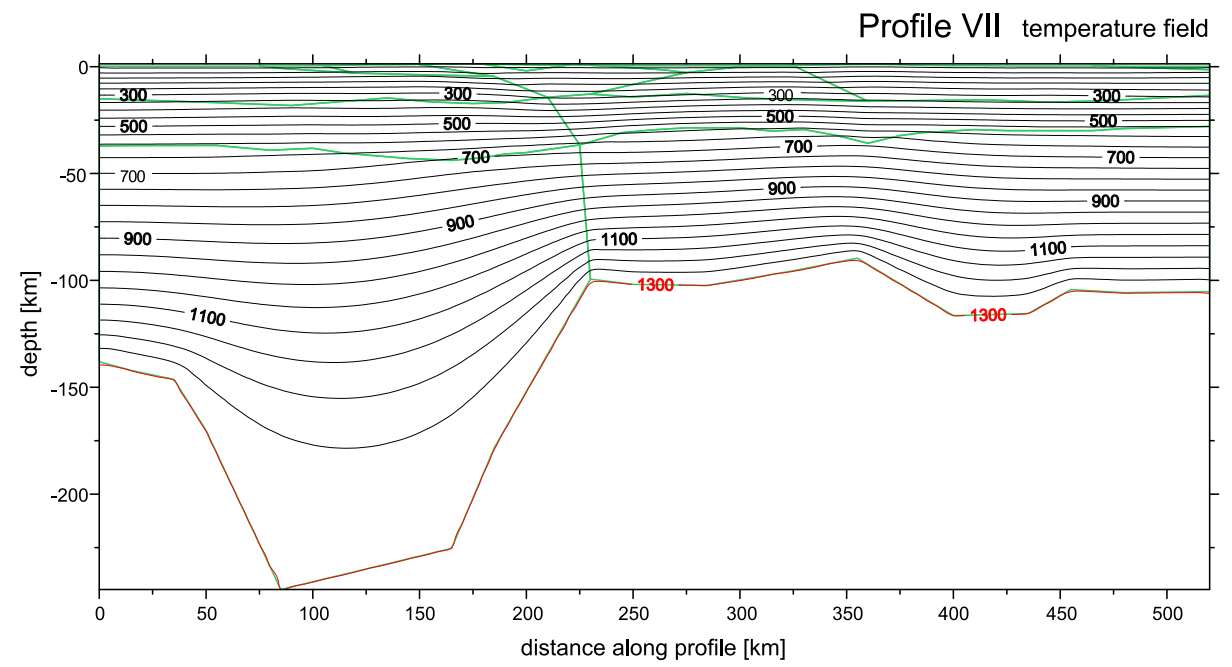

Fig. 3. Lithospheric temperature distribution calculated for profile VII, isolines every $200{ }^{\circ} \mathrm{C}$. The bottom of the model corresponds to the $1300{ }^{\circ} \mathrm{C}$ isotherm (red line). Green lines show contours of individual bodies comprising the lithospheric model. 
Table 1a. General properties used for producing the rheological model along the profile VII.

\begin{tabular}{|l|c|c|}
\hline Definition & Parameter & Value \\
\hline Gravity acceleration $\left[\mathrm{ms}^{-2}\right]$ & $g$ & 9.81 \\
\hline Universal gas constant $\left[\mathrm{J} \mathrm{mol} \mathrm{K}^{-1}\right]$ & $R$ & 8.314 \\
\hline Temperature at the base of the lithosphere $\left[{ }^{\circ} \mathrm{C}\right]$ & $T_{m}$ & 1300 \\
\hline Static friction coefficient & $f_{s}$ & 0.7 \\
\hline Strain rate $\left[\mathrm{s}^{-1}\right]$ & $\dot{\varepsilon}$ & $10^{-15}$ \\
\hline Hydrostatic pore fluid factor & $\lambda$ & 0.4 \\
\hline
\end{tabular}

Table 1b. Thermal and rheological parameters used for modelling along profile VII (after Carter and Tsenn (1987); Goetze and Evans (1979) and Lankreijer et al., (1999)). HP: heat production $\left(\mu \mathrm{Wm}^{-3}\right)$, TC: thermal conductivity $\left(\mathrm{Wm}^{-1} \mathrm{~K}^{-1}\right), \rho$ : density at room temperature $\left(\mathrm{kg} \mathrm{m}^{-3}\right), A_{p}$ : power law pre-exponential constant, $n$ : power law exponent, $E_{p}$ : power law activation energy $\left(\mathrm{kJ} \mathrm{mol}^{-1}\right)$.

\begin{tabular}{|r|l|c|c|c|c|c|c|}
\hline Nr. & Unit & HP & TC & Density & $\boldsymbol{A}_{\boldsymbol{p}}$ & $\boldsymbol{n}$ & $\boldsymbol{E}_{\boldsymbol{p}}$ \\
\hline 1 & Neogene sediments & 3.5 & 2.0 & 2400 & $3.16 \mathrm{E}-26$ & 3.30 & 186.5 \\
\hline 2 & Neogene sediments & 3.0 & 2.5 & 2400 & $3.16 \mathrm{E}-26$ & 3.30 & 186.5 \\
\hline 3 & $\begin{array}{l}\text { Flysch, foreland basin, sedimentary } \\
\text { cover of European Platform }\end{array}$ & 2.0 & 2.0 & 2500 & $3.16 \mathrm{E}-26$ & 3.30 & 186.5 \\
\hline 4 & $\begin{array}{l}\text { Flysch, foreland basin, sedimentary } \\
\text { cover of European Platform }\end{array}$ & 3.0 & 2.0 & 2400 & $3.16 \mathrm{E}-26$ & 3.30 & 186.5 \\
\hline 5 & Volcanics & 3.5 & 3.0 & 2800 & $3.16 \mathrm{E}-26$ & 3.30 & 186.5 \\
\hline 6 & $\begin{array}{l}\text { Carpathian and Pannonian upper } \\
\text { crust }\end{array}$ & 2.5 & 3.0 & 2740 & $3.16 \mathrm{E}-26$ & 3.30 & 186.5 \\
\hline 7 & $\begin{array}{l}\text { Carpathian and Pannonian upper } \\
\text { crust }\end{array}$ & 2.0 & 2.5 & 2740 & $3.16 \mathrm{E}-26$ & 3.30 & 186.5 \\
\hline 8 & $\begin{array}{l}\text { Carpathian and Pannonian upper } \\
\text { crust }\end{array}$ & 2.5 & 3.0 & 2760 & $3.16 \mathrm{E}-26$ & 3.30 & 186.5 \\
\hline 9 & European platform upper crust & 1.5 & 2.0 & 2750 & $3.16 \mathrm{E}-26$ & 3.30 & 186.5 \\
\hline 10 & $\begin{array}{l}\text { Carpathian and Pannonian lower } \\
\text { crust }\end{array}$ & 0.2 & 2.0 & 2930 & $6.31 \mathrm{E}-20$ & 3.05 & 276.0 \\
\hline 11 & European Platform lower crust & 0.2 & 2.0 & 2980 & $6.31 \mathrm{E}-20$ & 3.05 & 276.0 \\
\hline 12 & $\begin{array}{l}\text { Carpathian and Pannonian mantle } \\
\text { lithosphere }\end{array}$ & 0.05 & 3.4 & $3200+$ & $7.94 \mathrm{E}-18$ & 4.50 & 535.0 \\
\hline 13 & European mantle lithosphere & 0.05 & 3.4 & $3200+$ & $7.94 \mathrm{E}-18$ & 4.50 & 535.0 \\
\hline
\end{tabular}




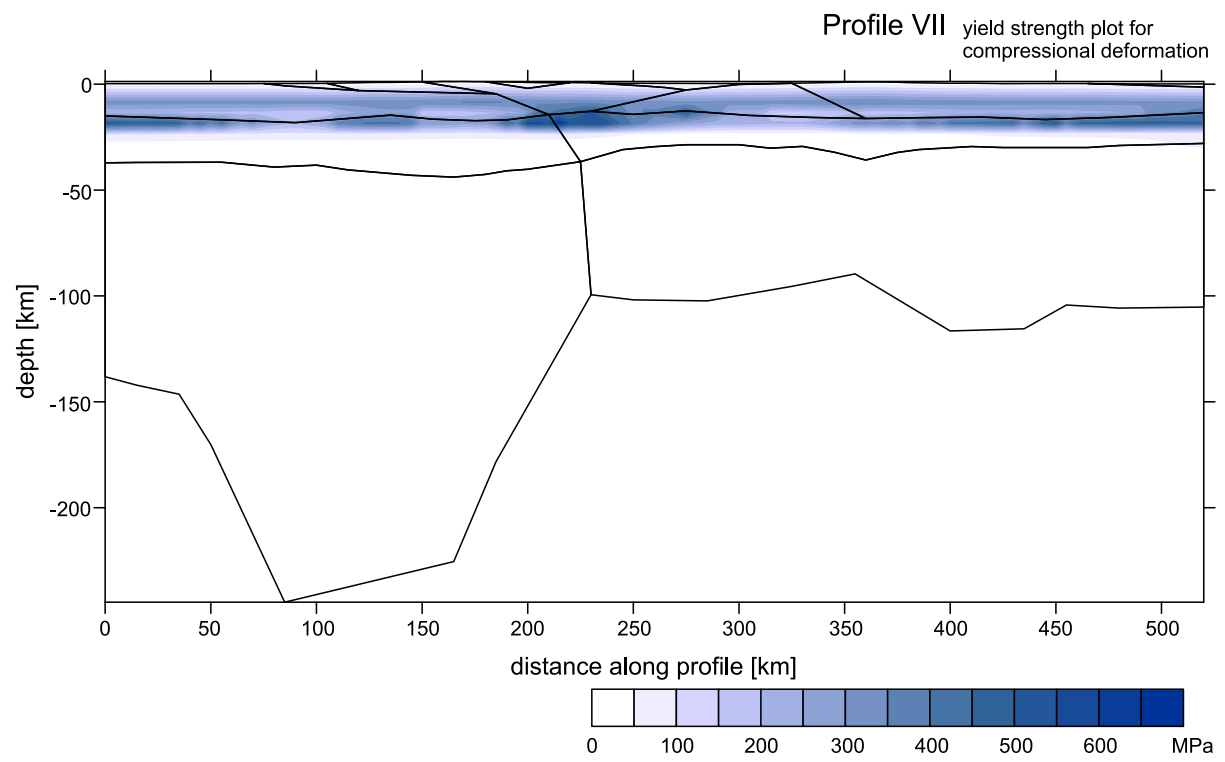

Fig. 4. Yield strength contour plot for compressional deformation calculated along profile VII respective to a strain rate $10^{-15} \mathrm{~s}^{-1}$.

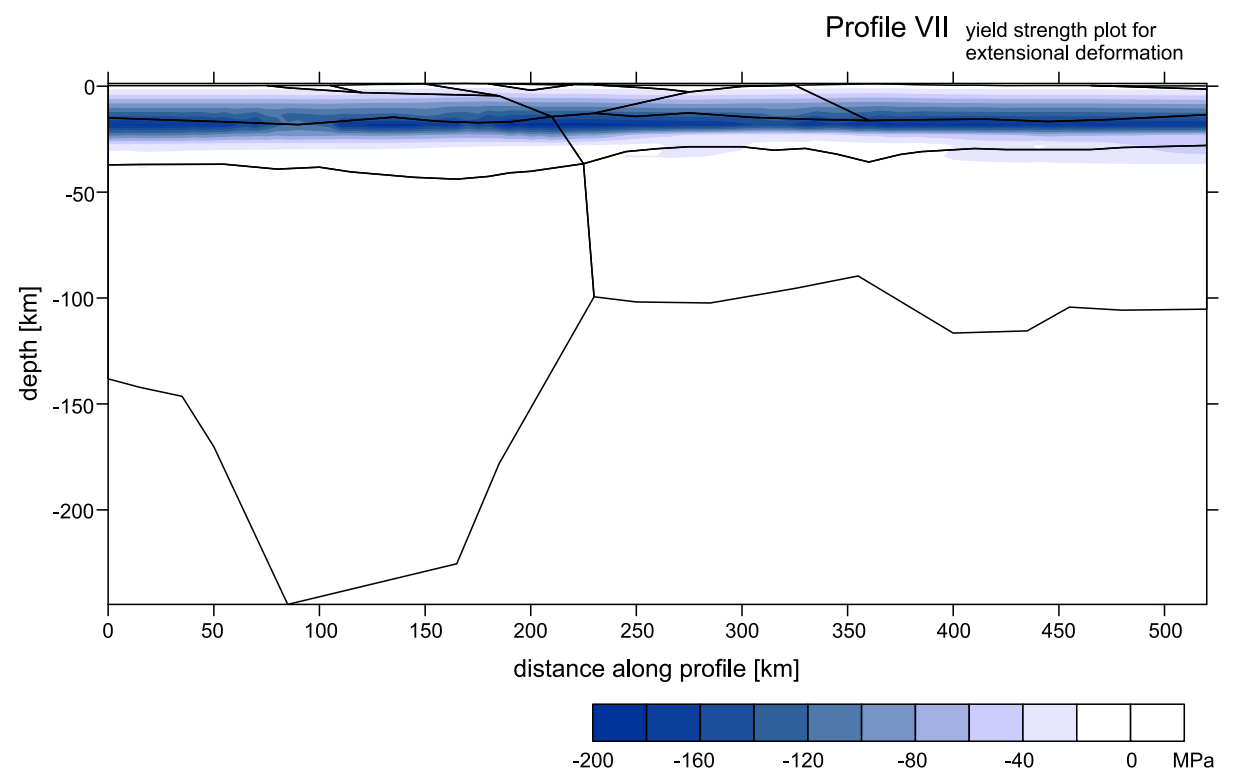

Fig. 5. Yield strength contour plot for extensional deformation calculated along profile VII respective to a strain rate $10^{-15} \mathrm{~s}^{-1}$. 
occurs on the boundary between the upper and lower crust. Compressional regime is dominant, with the highest values of strength in the Inner Eastern Carpathians. For extensional regime, the highest values can be observed in the Inner and Outer Eastern Carpathians.

The strength distribution, when integrated along vertical lithospheric columns, allows to compare the resistance of the lithosphere to stress in different areas. From Fig. 6 it is obvious that the highest strength (compressional) occurs in the Inner Eastern Carpathians. Following the calculated line, the strength decreases from its high values in the European platform towards its minimum in the Trans-European Suture Zone (TESZ). Then, it increases again, reaching a local maximum in the Outer Eastern Carpathians and the highest values in the Inner Eastern Carpathians. As the profile continues towards the Transylvanian Basin, the strength sharply drops and reaches a minimum in the Transylvanian Basin. Additional local maxima along the profile can be observed in the Apuseni Mountains.

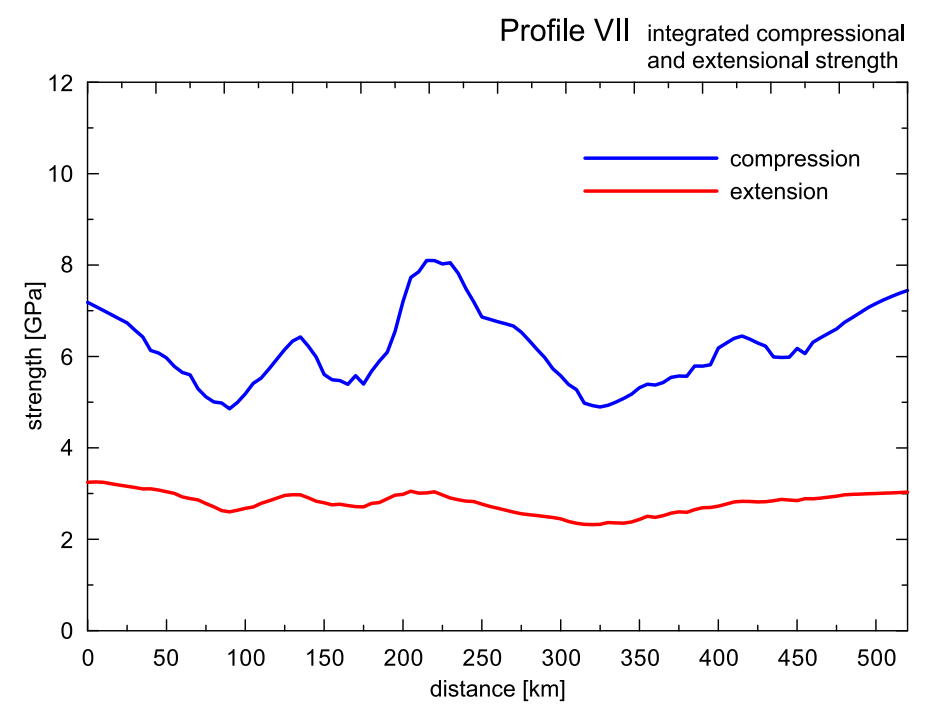

Fig. 6. Vertically integrated compressional (blue line) and extensional (red line) strength calculated along profile VII.

To better illustrate the strength distribution in distinguished tectonic units of which the lithosphere is composed along profile VII, we have calculated strength distribution for selected lithospheric columns and constructed the yield strength envelopes along the profile, namely for columns located in 

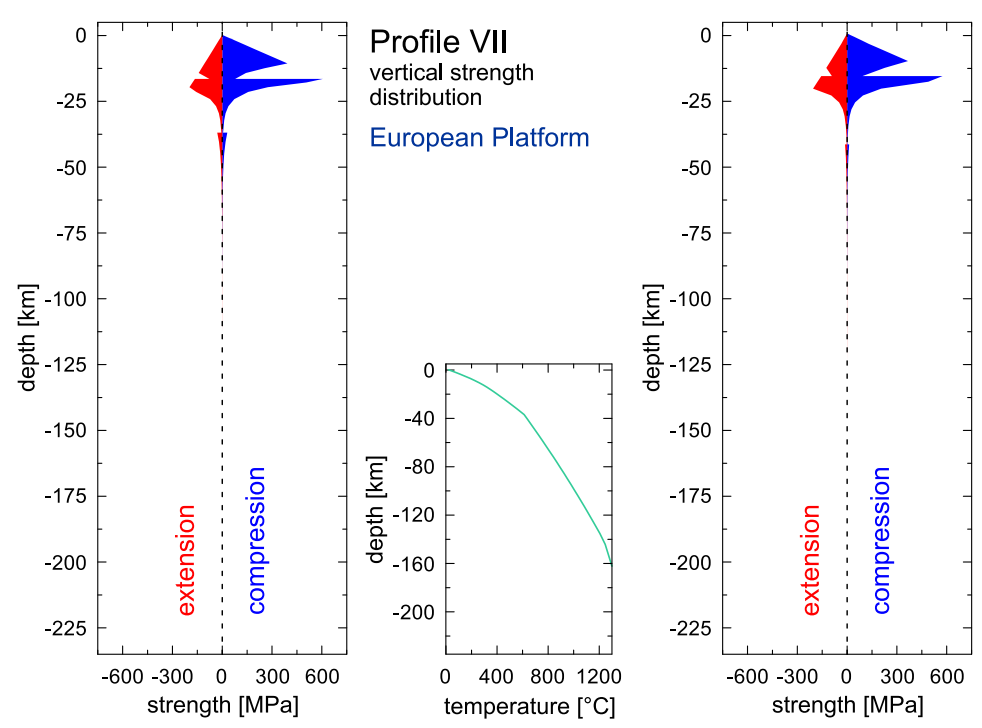

\section{Profile VII}

vertical strength

distribution

Outer Eastern

Carpathians
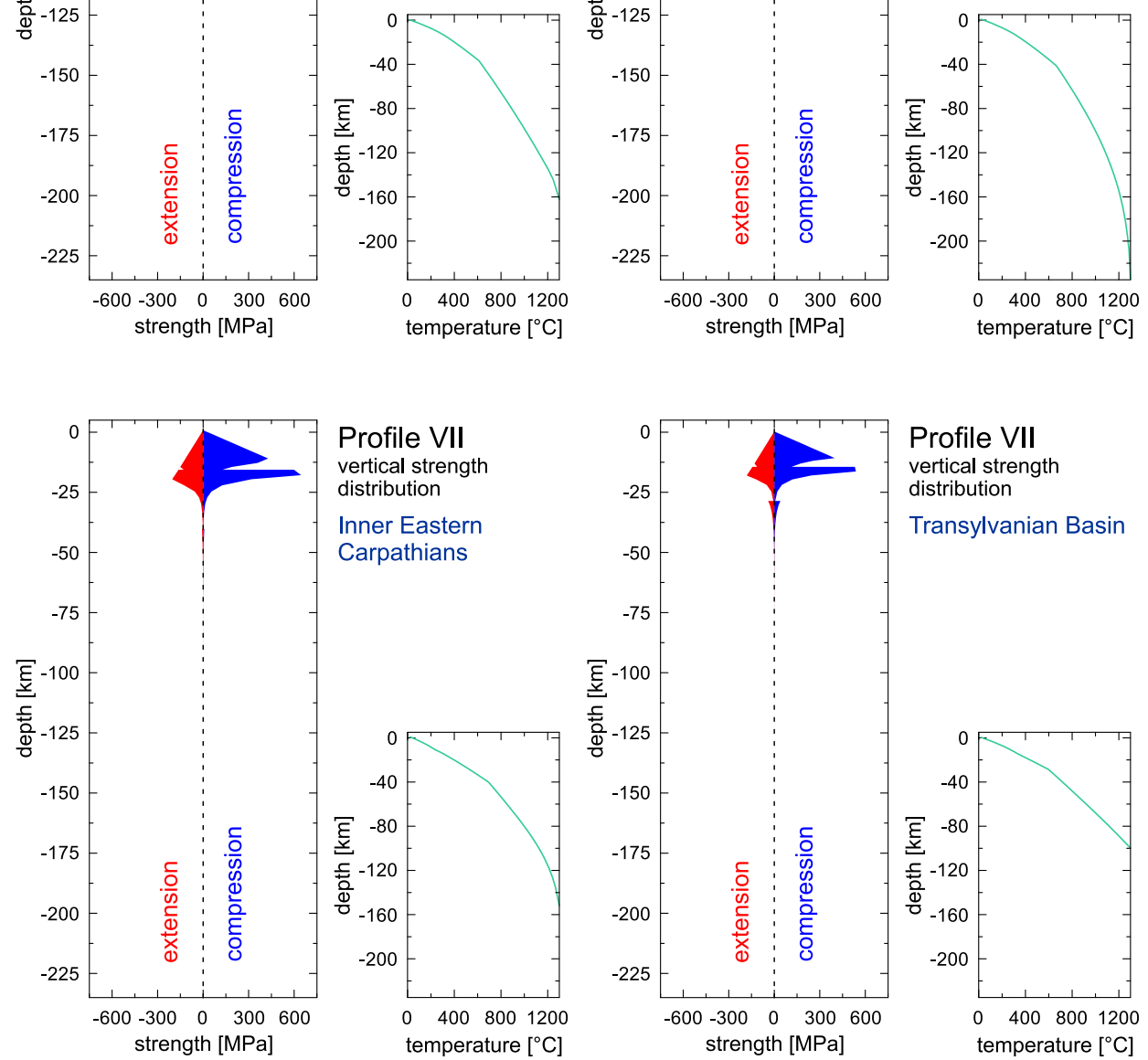

Profile VII

vertical strength distribution

Transylvanian Basin

Fig. 7. Vertical strength distribution for different lithospheric columns calculated along profile VII. Negative and positive values correspond to extensional and compressional strength, respectively. 

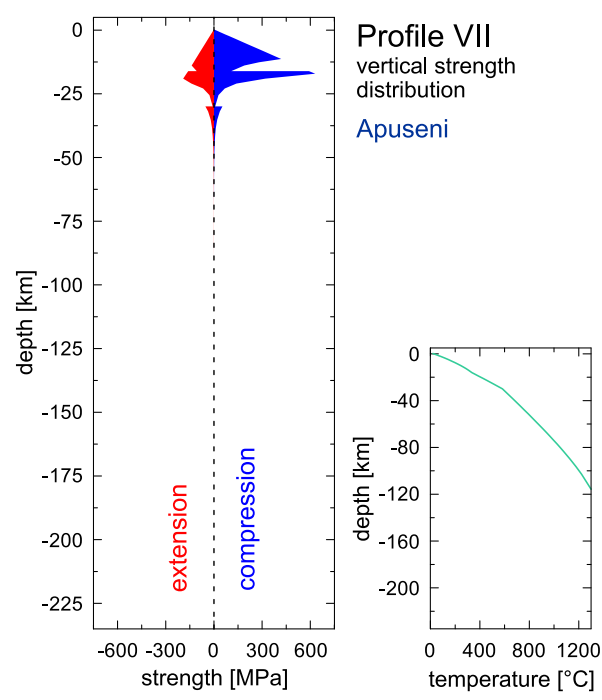

Fig. 7. Continued.

the European Platform, the Outer Eastern Carpathians, the Inner Eastern Carpathians, the Transylvanian Basin and the Apusenis (Fig. 7). The yield strength envelope is represented by the curves of two different types. At shallow depths, the straight line corresponding to brittle failure shows the increase of strength with depth. The curved line, corresponding to ductile deformation, shows the decrease of strength with depth exponentially due to temperature increase.

\section{Conclusions}

We have used 2D integrated geophysical modelling to derive a rheological model of the lithosphere along the profile in the Eastern Carpathians. We have calculated the strength distribution in the lithosphere (based on the brittle and ductile deformation) for compressional and extensional regimes, vertically integrated strength, and the yield strength envelopes for chosen tectonic units. Our results imply that different tectonic units show different rheological behavior and appear to be in agreement with their lithospheric structure and tectonics. The dominant regime is compressional along the 
whole profile and the largest strength occurs on the boundary between the upper and lower crust. Maxima of strength can be observed in the European Platform, and in the Inner and Outer Eastern Carpathians. The largest strength most likely reflects the deep collision between the East European Craton (the European platform) and the microplate Tisza-Dacia. The Trans-European Suture Zone (TESZ) is characterized by low values of lithospheric strength. This result could correspond to the fact that this tectonic unit is very old, without present tectonic activity. The Transylvanian basin is also represented by low values of lithospheric strength, but here it could be related to the fact that the basin is a young tectonic unit, which is characterized by higher surface heat flow. Small maximum occurs also in the Apuseni Mountains.

Acknowledgements. This research was supported by the Slovak Grant Agency VEGA, grant No. 2/0006/19, by the Slovak Research and Development Agency under grants APVV-16-0146 (acronym WECAFARE), APVV-16-0482 (acronym LITHORES) and APVV-19-0150 (acronym ALCABA). Rheological lithospheric problems have also been investigated in the frame of the ILP (CoLiBrI), the AdriaArray and the Visegrad Grant CAPABLE (No. 21930053) projects. Authors are grateful to Prof. Hermann Zeyen of University de la Terre for permission to use 2D integrated modelling software (CAGES).

\section{References}

Alasonati Tašárová A., Afonso J. C., Bielik M., Götze H.-J., Hók J., 2009: The lithospheric structure of the Western Carpathian-Pannonian Basin region based on the CELEBRATION 2000 seismic experiment and gravity modelling. Tectonophysics, 475, 3-4, 454-469, doi: 10.1016/j.tecto.2009.06.003.

Alasonati Tašárová Z., Fullea J., Bielik M., Środa P., 2016: Lithospheric structure of Central Europe: Puzzle pieces from Pannonian Basin to Trans-European Suture Zone resolved by geophysical-petrological modeling. Tectonics, 35, 3, 722-753, doi: $10.1002 / 2015$ TC003935.

Andreescu M., Demetrescu C., 2001: Rheological implications of the thermal structure of the lithosphere in the convergence zone of the Eastern Carpathians. J. Geodyn., 31, 4, 373-391, doi: 10.1016/S0264-3707(01) 00008-4.

Belka Z., Valverde-Vaquero P., Dörr W., Ahrendt H., Wemmer K., Franke W., Schäffer J., 2002: Accretion of the first Gondwana-derived terranes at the margin of Baltica. In: Winchester J. A., Pharaoh T. C., Verniers J. (Eds.): Palaeozoic Amalgamation of Central Europe. Geol. Soc., London, Spec. Publ.,201, 19-36, doi : 10.1144/GSL.SP. 2002.201.01.02.

Bielik M., 1998: Analysis of the gravity field in the Western and Eastern Carpathian junction area: density modeling. Geologica Carpathica, 49, 2, 75-83. 
Bielik M., Stríženec P., 1994: Flexure of the lithosphere beneath the Pannonian Basin. Contrib. Geophys. Geod., 24, 1, 87-104.

Bielik M., Ursíny M., 1997: Flexure of the elastic plate. Contrib. Geophys. Geod., 27, 1, 81-93.

Bielik M., Makarenko I., Starostenko V., Legostaeva O., Dérerová J., Šefara J., Pašteka R., 2005: New 3D gravity modelling in the Carpathian-Pannonian region. Contrib. Geophys. Geod., 35, 1 65-78.

Boykova A., 1999: Moho discontinuity in central Balkan Peninsula in the light of the geostatistical structural analysis. Phys. Earth Planet. Inter., 114, 1-2, 49-58, doi : 10.1016/S0031-9201(99)00045-X.

Burov E. B., Diament M., 1995: The effective elastic thickness $\left(T_{e}\right)$ of continental lithosphere: What does it really mean? J. Geophys. Res. Solid Earth, 100, B3, 39053927, doi : 10.1029/94JB02770.

Byerlee J., 1978: Friction of rocks. Pure Appl. Geophys., 116, 4-5, 615-626, doi: 10.1007 /BF00876528.

Carter N. L., Tsenn M. C., 1987: Flow properties of continental lithosphere. Tectonophysics, 136, 1-2, 27-63, doi: 10.1016/0040-1951(87)90333-7.

Csontos L., Nagymarosy A., Horváth F., Kováč M., 1992: Tertiary evolution of the IntraCarpathian area: A model. Tectonophysics, 208,1-3, 221-241, doi: 10.1016/00401951 (92) 90346-8.

Dadlez R., Kowalczewski Z., Znosko J., 1994: Some key problems of the pre-Permian tectonics of Poland. Geol. Q., 38, 2, 169-190.

Dadlez R., Narkiewicz M., Stephenson R. A., Visser M. T. M., van Wees J. D., 1995: Tectonic evolution of the Mid-Polish Trough: Modelling implications and significance for Central European geology. Tectonophysics, 252, 1-4, 179-195, doi: 10.1016/00 40-1951 (95) 00104-2.

Dadlez R., 2001: Holy Cross Mts. area - crustal structure, geophysical data and general geology. Geol. Q., 45, 2, 99-106.

Demetrescu C., Wilhelm H., Tumanian M., Nielsen S. B., Damian A., Dobrică V., Ene M., 2007: Time-dependent thermal state of the lithosphere in the foreland of the Eastern Carpathians bend. Insights from new geothermal measurements and modelling results. Geophys .J. Int., 170, 2, 896-912, doi: 10.1111/j.1365-246X.2007.03408.x.

Dérerová J., Zeyen H., Bielik M., Salman K., 2006: Application of integrated geophysical modeling for determination of the continental lithospheric thermal structure in the eastern Carpathians. Tectonics, 25, 3, TC3009, doi: 10.1029/2005TC001883.

Dérerová J., Kohút I., Bielik M., Bošanský M., Porubčanová B., 2012: Calculation of temperature distribution and rheological properties of the lithosphere along profile I in the Western Carpathians. Contrib. Geophys. Geod., 42, 4, 345-356, doi : 10.2478/ v10126-012-0016-5.

Dérerová J., Bielik M., Pašiaková M., Kohút I., Hlavňová P., 2014: Calculation of temperature distribution and rheological properties of the lithosphere along transect II in the Western Carpathian-Pannonian Basin region. Contrib. Geophys. Geod., 44, 2, 149-160, doi: 10.2478/congeo-2014-0009. 
Dérerová J., Bielik M., Kohút I., Godová D., 2019: Calculation of temperature distribution and rheological properties of the lithosphere along transect IV in the Western Carpathian-Pannonian Basin region. Contrib. Geophys. Geod., 49, 4, 497-510. doi: 10.2478/congeo-2019-0026.

Fan G., Wallace T. C., Zhao D., 1998: Tomographic imaging of deep velocity structure beneath the Eastern and Southern Carpathians, Romania: Implications for continental collision. J. Geophys. Res. Solid Earth, 103, B2, 2705-2723, doi : 10.1029/97JB0 1511.

Goetze C., Evans B., 1979: Stress and temperature in the bending lithosphere as constrained by ex-perimental rocks mechanics. Geophys. J. R. Astron. Soc., 59, 3, 463-478, doi: 10.1111/j.1365-246X.1979.tb02567.x.

Grad M., Guterch A., Keller G. R., Janik T., Hegedüs E., Vozár J., Ślaczka A., Tiira T., Yliniemi J., 2006: Lithospheric structure beneath trans-Carpathian transect from Precambrian platform to Pannonian basin: CELEBRATION 2000 seismic profile CEL05. J. Geophys. Res. Solid Earth, 111, B3, B03301, doi: 10.1029/2005JB00 3647.

Grinč M., Zeyen H., Bielik M., Plašienka D., 2013: Lithospheric structure in Central Europe: Integrated geophysical modelling. J. Geodyn., 66, 13-24, doi: 10.1016/j . jog. 2012.12.007.

Hauser F., Raileanu V., Fielitz W., Dinu C., Landes M., Bala A., Prodehl C., 2007: Seismic crustal structure between the Transylvanian Basin and the Black Sea, Romania. Tectonophysics, 430,1-4, 1-25, doi : 10.1016/j.tecto.2006.10.005.

Horváth F., 1993: Towards a mechanical model for the formation of the Pannonian Basin. Tectonophysics, 226, 1-4, 333-357, doi: 10.1016/0040-1951(93)90126-5.

Horváth F., Szalay A., Dövényi P., Rumpler J., 1986: Structural and thermal evolution of the Pannonian basin: an overview. In: Burrus J. (Ed.): Thermal modelling in sedimentary basins. Edition Technip, Paris, Collection Colloques et Séminaires, 44, 339-358.

Ionescu C., Hoeck V., Tomek C., Koller F., Balintoni I., Beşuţiu L., 2009: New insights into the basement of the Transylvanian Depression (Romania). Lithos, 108, 1-4, 172-191, doi: 10.1016/j.lithos.2008.06.004.

Janik T., Grad M., Guterch A., Vozár J., Bielik M., Vozárová A., Hegedűs E., Kovács C. A., Kovács I., Keller G. R., CELEBRATION 2000 Working Group, 2011: Crustal structure of the Western Carpathians and Pannonian Basin: Seismic models from CELEBRATION 2000 data and geological implications. J. Geodyn., 52, 2, 97-113, doi : $10.1016 / j \cdot j o g .2010 .12 .002$.

Kohlstedt D. L., Evans B., Mackwell S. J., 1995: Strength of the lithosphere: Constraints imposed by laboratory experiments. J. Geophys. Res. Solid Earth, 100, B9, 17,58717,602, doi : 10.1029/95JB01460.

Koulakov I., Zaharia B., Enescu B., Radulian M., Popa M., Parolai S., Zschau J., 2010: Delamination or slab detachment beneath Vrancea? New arguments from local earthquake tomography. Geochem. Geophys. Geosyst., 11, 3, Q03002, doi : 10.1029 /2009GC002811. 
Kováč M., 2000: Geodynamic, paleogeographic and structural evolution of the CarpathianPannonian region in Miocene: A new view on the Neogene basins of Slovakia (Geodynamický, paleogeografický a štruktúrny vývoj karpatsko-panónskeho regiónu v miocéne: Nový pohlad na neogénne panvy Slovenska). Veda, Bratislava, 204 p. (in Slovak).

Lankreijer A., Mocanu V., Cloetingh S., 1997: Lateral variations in lithosphere strength in the Romanian Carpathians: constraints on basin evolution. Tectonophysics, 272, 2-4, 269-290, doi : 10.1016/S0040-1951(96)00262-4.

Lankreijer A., Bielik M., Cloetingh S., Majcin D., 1999: Rheology predictions across the western Carpathians, Bohemian Massif, and the Pannonian Basin: Implications for tectonic scenarios. Tectonics, 18, 6, 1139-1153, doi : 10.1029/1999TC900023.

Lazarescu V., Cornea L., Radulescu F., Popescu M., 1983: Moho surface and recent crustal movements in Romania. Geodynamic connections. Ann. Inst. Geol. Geofiz., 63, 83-91.

Lenkey L., 1999: Geothermics of the Pannonian Basin and its bearing on the tectonics of basin evolution. PhD. thesis, Free University, Amsterdam, 215 p.

Lewandowski M., 1993: Paleomagnetism of the Paleozoic rocks of the Holy Cross Mts (central Poland) and the origin of the Variscan orogen. Publ. Inst. Geophys. Pol. Acad. Sci., A-23, 265, 1-85.

Malinowski M., Żelaźniewicz A., Grad M., Guterch A., Janik T., CELEBRATION Working Group, 2005: Seismic and geological structure of the crust in the transition from Baltica to Palaeozoic Europe in SE Poland - CELEBRATION 2000 experiment, profile CEL02. Tectonophysics, 401, 1-2, 55-77, doi: 10.1016/j.tecto.2005.03.011.

Malinowski M., Środa P., Grad M., Guterch A., CELEBRATION 2000 Working Group, 2009: Testing robust inversion strategies for three-dimensional Moho topography based on CELEBRATION 2000 data. Geophys. J. Int., 179, 2, 1093-1104. doi: 10. 1111/j.1365-246X.2009.04323.x.

Malinowski M., Guterch A., Narkiewicz M., Probulski J., Maksym A., Majdański M., Środa P., Czuba W., Gaczyński E., Grad M., Janik T., Jankowski L., Adamczyk A., 2013: Deep seismic reflection profile in Central Europe reveals complex pattern of Palaeozoic and Alpine accretion at the East European Craton margin. Geophys. Res. Lett., 40, 15, 3841-3846, doi : 10.1002/grl.50746.

Mocanu V., Radulescu F., 1994: Geophysical features of the Romanian territory. Rom. J. Tect. Reg. Geol., 75, 17-36.

Mucuta D. M., Knapp C. C., Knapp J. H., 2006: Constraints from Moho geometry and crustal thickness on the geodynamic origin of the Vrancea Seismogenic Zone (Romania). Tectonophysics, 420, 1-2, 23-36, doi: 10.1016/j.tecto.2006.01.018.

Pharaoh T. C., 1999: Palaeozoic terranes and their lithospheric boundaries within the Trans-European Suture Zone, TESZ: a review. Tectonophysics, 314, 1-3, 17-41, doi : 10.1016/S0040-1951(99)00235-8.

Pharaoh T. C., Winchester J. A., Verniers J., Lassen A., Seghedi A., 2006: The western accretionary margin of the East European Craton: an overview. In: Gee D. G., Stephenson R. A. (Eds.): European Lithosphere Dynamics. Geol. Soc. Lond. Mem., 32, 291-311, doi: 10.1144/GSL.MEM.2006.032.01.17. 
Plašienka D., 2018: Continuity and episodicity in the early Alpine tectonic evolution of the Western Carpathians: How large-scale processes are expressed by the orogenic architecture and rock record data. Tectonics, 37, 7, 2029-2079, doi: 10.1029/2017TC00 4779 .

Ranalli G., 1995: Rheology of the Earth (2nd ed.). London, New York: Chapman \& Hall, $413 \mathrm{p}$.

Ratschbacher L., Merle O., Davy Ph., Cobbold P., 1991a: Lateral extrusion in the eastern Alps, Part 1: Boundary conditions and experiments scaled for gravity. Tectonics, 10, 2, 245-256, doi : 10.1029/90TC02622.

Ratschbacher L., Frisch W., Linzer H.-G., Merle O., 1991b: Lateral extrusion in the eastern Alps, Part 2: Structural analysis. Tectonics, 10, 2, 257-271, doi: 10.1029/90TC 02623.

Raykova R. B., Panza G. F., 2006: Surface waves tomography and non-linear inversion in the southeast Carpathians. Phys. Earth Planet. Inter., 157, 3-4, 164-180, doi: 10.1016/j.pepi.2006.03.019.

Sanders C., Huismans R., van Wees J. D., Andriessen P., 2002: The Neogene history of the Transylvanian basin in relation to its surrounding mountains. EGU Stephan Mueller Spec. Publ. Ser., 3, 121-133, doi: 10.5194/smsps-3-121-2002.

Săndulescu M., 1994: Overview on Romanian geology. In: Alcapa II Field Guide Book. Rom. J. Tect. Reg. Geol., 75, suppl. 2, 3-15.

Schmid S. M., Bernoulli D., Fügenschuh B., Matenco L., Schefer S., Schuster R., Tischler M., Ustaszewski K., 2008: The Alpine-Carpathian-Dinaridic orogenic system: correlation and evolution of tectonic units. Swiss J. Geosci., 101, 1, 139-183, doi : $10.1007 / \mathrm{s} 00015-008-1247-3$.

Schuller V., Frisch W., Danišík M., Dunkl I., Melinte M. C., 2009: Upper Cretaceous Gosau deposits of the Apuseni Mountains (Romania) - similarities and differences to the Eastern Alps. Austrian J. Earth Sci., 102, 1, 133-145.

Środa P., Czuba W., Grad M., Guterch A., Tokarski A. K., Janik T., Rauch M., Keller G. R., Hegedüs E., Vozár J., CELEBRATION 2000 Working Group, 2006: Crustal and upper mantle structure of the Western Carpathians from CELEBRATION 2000 profiles CEL01 and CEL04: seismic models and geological implications. Geophys. J. Int., 167, 2, 737-760, doi: 10.1111/j.1365-246X.2006.03104.x.

Szafián P., Horváth F., Cloetingh S., 1997: Gravity constraints on the crustal structure and slab evolution along a Transcarpathian transect. Tectonophysics, 272, 2-4, 233-247, doi: 10.1016/S0040-1951(96)00260-0.

Wenzel F., Sperner B., Lorenz F., Mocanu V., 2002: Geodynamics, tomographic images and seismicity of the Vrancea region (SE-Carpathians, Romania). EGU Stephan Mueller Spec. Publ. Ser., 3, 95-104, doi: 10.5194/smsps-3-95-2002.

Wortel M. J. R., Spakman, W., 2000: Subduction and slab detachment in the Mediterranean-Carpathian region. Science, 290, 5498, 1910-1917, doi: 10.1126/science. 290.5498.1910. 